University of Nebraska - Lincoln

DigitalCommons@University of Nebraska - Lincoln

Investigations of the Ichthyofauna of

Nicaraguan Lakes

Papers in the Biological Sciences

1976

\title{
Parental behavior and some histological features of scales in Cichlasoma citrinellum (pisces, Cichlidae)
}

David L. G. Noakes

University of Guelph

Follow this and additional works at: https://digitalcommons.unl.edu/ichthynicar

Part of the Aquaculture and Fisheries Commons

Noakes, David L. G., "Parental behavior and some histological features of scales in Cichlasoma citrinellum (pisces, Cichlidae)" (1976). Investigations of the Ichthyofauna of Nicaraguan Lakes. 32.

https://digitalcommons.unl.edu/ichthynicar/32

This Article is brought to you for free and open access by the Papers in the Biological Sciences at DigitalCommons@University of Nebraska - Lincoln. It has been accepted for inclusion in Investigations of the Ichthyofauna of Nicaraguan Lakes by an authorized administrator of DigitalCommons@University of Nebraska Lincoln. 


\title{
Parental behavior and some histological features of scales in Cichlasoma citrinellum (Pisces, Cichlidae)
}

\author{
DAVID L. G. NoAKES 1 \\ Zoology Department, University of Edinburgh, Edinburgh, Scotland
}

Received November 30, 1972

\begin{abstract}
NoAKes, D. L. G. 1973. Parental behavior and some histological features of scales in Cichlasoma citrinellum (Pisces, Cichlidae). Can. J. Zool. 51: 619-622.

Young Cichlasoma citrinellum contact parents preferentially, depending on sex and color of the parents. The number of epidermal mucus cells on adults' scales is positively correlated with the amount of contacting by the young. The epidermal thickness of these scales is negatively correlated with the amount of contacting. These correlations are discussed as possible cause-effect relationships with the contacting preferences of the young, and are compared to similar behavior in other cichlid fish species.
\end{abstract}

NOAKES, D. L. G. 1973. Parental behavior and some histological features of scales in Cichlasoma citrinellum (Pisces, Cichlidae). Can. J. Zool. 51: 619-622.

Chez les Cichlasoma citrinellum juvéniles, le contact avec les parents est préférentiel et dépend du sexe et de la coloration du parent. Il y a une corrélation positive entre le nombre de cellules muqueuses épidermiques présentes sur les écailles des adultes et le nombre de contacts tentés par le jeune. Par contre, l'épaisseur d'épiderme sur ces écailles est en relation inverse avec la recherche des contacts. On se demande s'il n'y aurait pas une relation de cause à effet entre ces corrélations et les préférences des jeunes; on compare ces résultats avec des comportements semblables observés chez d'autres espèces de Cichlidae.

[Traduit par le journal]

\section{Introduction}

We have described elsewhere the ontogeny of behavior of young Cichlasoma citrinellum, and some aspects of the behavior of the parents during the corresponding period (Noakes and Barlow 1968, 1973a, 1973b). Adults are polymorphic in body color, the "normal" color being grey; the "gold" morphs are more or less xanthic and lack the species typical dark markings (Barlow 1973; and in preparation). The young have a characteristic behavior directed toward the parents in both the laboratory and the field. About 4 days after the young become free-swimming, they begin to feed from the body surfaces of the parents, an action termed contacting. Initially they contact either parent equally. With age they contact a male parent increasingly more than a female, and a greycolored parent of either sex more than a xanthic one; these two factors can be combined, producing a heightened response, as with a normal male and a gold female, or cancelling each other, as with a gold male and a normal female.

We found that there was some immediate feature(s) of preferred parents to which the young responded (Noakes and Barlow 1973b).

1Present address: Department of Zoology, College of Biological Science, University of Guelph, Guelph, Ontario, Canada.
Since we were interested in the development of this selective responsiveness, we gave some thought to the possible cues to which young might be responding. Others (e.g. Baerends and Baerends-van Roon 1950; Kuenzer 1968; Kuhme 1962; Noble and Curtis 1939; Peters 1963) have investigated some of the cues to which young cichlids respond, but in this species the question is of particular importance because it relates to the polymorphism of the species. A first thought was of the condition of the parents' surfaces, particularly the production of epidermal mucus.

A relationship between epidermal mucus production and parental behavior in cichlid fish has been reported before (Hildemann 1959; Blüm 1968; Heinrich 1967; Ward and Barlow 1967). Accordingly, I undertook a preliminary study of scale samples from adult $C$. citrinellum to look for any correlation between mucus production and contacting by the young fish.

\section{Methods}

Details of the source and treatment of fish are given elsewhere (Noakes and Barlow 1973b). Fish for this study were typical, healthy adults in various stages of the parental cycle, which happened to be available in the laboratory at the time (Table 1).

Individual scales were carefully removed with fine forceps, taking two scales from each of three locations, dorsal (a few scale rows down from the base of the dorsal fin), middle (midlateral surface), and ventral (a few 
IABLE 1

Relative amounts of contacting (ranks) to adults used in this series

\begin{tabular}{|c|c|c|c|}
\hline Fish & $\begin{array}{l}\text { Parental state } \\
\text { (pair) }\end{array}$ & $\begin{array}{l}\text { Amount of } \\
\text { contacting }\end{array}$ & Rank \\
\hline (1) $\mathrm{N}$ ㅇ & Nonparental & None & 1.5 \\
\hline (2) $G$ o & Nonparental & None & 1.5 \\
\hline (7) $\mathrm{N} 0^{7 *}$ & Early parental $(\mathrm{N} \times \mathrm{G})$ & None-low & 3 \\
\hline (6) G 우 & Late parental $(\mathrm{N} \times \mathrm{G})$ & Low-medium & 4 \\
\hline (3) $\mathrm{G} \sigma^{7}$ & Late parental $(\mathrm{G} \times \mathrm{N})$ & Medium & 5 \\
\hline (8) $N \sigma^{7 *}$ & Midparental $(\mathrm{N} \times \mathrm{N})$ & Medium-high & 6 \\
\hline (5) $\mathrm{N} \sigma^{7 *}$ & Late parental $(\mathrm{N} \times \mathbf{G})$ & High & 7 \\
\hline (4) $G \sigma^{7 *}$ & Late parental $(\mathrm{G} \times \mathrm{G})$ & Higher & 8 \\
\hline
\end{tabular}

scale rows up from the bottom) on the right side of the body of each fish. Scales were immediately fixed in fresh Perenyi's fixative (Humason 1962), dehydrated through an alcohol series, and embedded in paraffin, as in Ward and Barlow (1967). Serial sections $(10 \mu \mathrm{m})$ were routinely stained with haematoxylin and eosin. Sections were examined at $400 \times$. Goblet mucus cells counted were generally dark staining, 3-5 $\mu \mathrm{m}$ in diameter (Fig. 1). Smaller cells or similar staining masses (peripheral sections of adjacent cells) were not counted. Using an ocular micrometer, epidermal thickness was measured at three points on each section, on a different occasion from the counting of mucus cells. Slides were identified only by code letter and number to reduce bias in scoring. A minimum of $25 \mathrm{~mm}$ total length of scale tissue was examined for each fish (average of $93 \mathrm{~mm}$ for all fish).

\section{Results}

From our previous findings (Noakes and Barlow 1973b) and from the protocols for these fish, relative values as to the amount of contacting received from young were assigned to each fish (Table 1). The rank of 1 was assigned to nonparental fish because they were not being contacted by young. The highest rank was given to highly preferred parents (males, and greycolored fish) late in the parental cycle. Other fish were assigned intermediate ranks, depending on their particular circumstances. As protocols were not available for all fish, and conditions for each parent, e.g. numbers of young, amount of feeding, were not uniform, it was not meaningful to assign precise, numerical values for the amount of contacting received.

Counts of mucus cells on scales from different locations had some suggestion of differences, but there was not enough consistency, or large enough samples, to justify consideration of scales from different locations separately. Therefore counts were combined for all scales for each fish, and compared to other fish (Table 2).

Measurements of scale epidermal thickness were also combined for each fish, and compared in a similar manner (Table 2).

There is an obvious relationship between number of epidermal mucus cells and being parental in C. citrinellum. All parental fish had significantly more mucus cells than did nonparental adults. Further, there was a positive correlation between numbers of mucus cells and amount of contacting by young fish $\left(\gamma_{\mathrm{s}}=\right.$ $0.71 ; 0.01<p<0.05$, Spearman rank correlation coefficient; Siegel 1956). There were also significant differences in numbers of cells among different parental fish, but we must exercise caution in interpreting them, as the sampling is not yet complete.

The epidermis was significantly thicker in nonparental than in parental adults. And there is a significant negative correlation $\left(\gamma_{\mathrm{s}}=0.81\right.$; $0.01<p<0.05$ ) between amount of contacting and epidermal thickness in adults (Table 2).

\section{Discussion}

The present findings are in general agreement with the few other reports of epidermal histology and parental behavior in cichlids. The number of epidermal goblet mucus cells in nonparental adult $C$. citrinellum (four to five per millimeter) corresponds fairly well to that found in nonparental Etroplus maculatus, the orange chromide (five to six per millimeter), by Ward and Barlow (1967). They recorded an increase to about eight cells per millimeter early in the parental cycle. In comparison, I found more than 40 cells per millimeter in some parental fish. Hildemann (1959) reported increased numbers of mucus cells in parental Symphysodon discus, the discus fish, but did not give any quantitative measures, so a precise comparison is not possible. Similarly, Heinrich (1967) mentioned a great increase in epidermal mucus in parental male Tilapia macrocephala, the black-chinned mouthbreeder, and Blüm (1968) referred to the increase in epidermal mucus production as typical of some other cichlid species, but no data were given. Young Etroplus maculatus and Symphosydon discus feed on 
TABLE 2

Mean number of mucus cells, mean epidermal thickness, and their ranks, for different fish. (Means with standard errors)

\begin{tabular}{cccccc}
\hline & $\begin{array}{c}\text { Mucus } \\
\text { cells, } \\
\text { per mm }\end{array}$ & Rank & $\begin{array}{c}\text { Epidermal } \\
\text { thickness, } \\
\times 0.016 \mathrm{~mm}\end{array}$ & Rank & $\begin{array}{c}\text { Contact } \\
\text { rank }\end{array}$ \\
\hline (1) & $4.08(0.62)$ & 1 & $2.64(0.07)$ & 1 & 1.5 \\
(2) & $4.55(1.11)$ & 2 & $2.25(0.10)$ & 2 & 1.5 \\
(7) & $9.99(1.18)$ & 3 & $1.95(0.04)$ & 6.5 & 3 \\
(6) & $11.60(0.67)$ & 6 & $2.03(0.04)$ & 3 & 4 \\
(3) & $11.58(1.25)$ & 5 & $2.02(0.04)$ & 4 & 5 \\
(8) & $45.13(1.55)$ & 8 & $1.99(0.05)$ & 5 & 6 \\
(5) & $21.79(1.30)$ & 7 & $1.95(0.04)$ & 6.5 & 7 \\
(4) & $10.44(0.81)$ & 4 & $1.26(0.03)$ & 8 & 8
\end{tabular}

mucus from the surface of the parents, but this is not the case for young Tilapia macrocephala, at least outside the buccal cavity. In a few other species of cichlids it seems likely that young may at times feed on mucus from their parents (Noakes 1971), but nothing has been reported as to the production of epidermal mucus by the parents in those species.

The significant positive correlation between numbers of mucus cells and amount of contacting by young fish in $C$. citrinellum (Table 2) suggests that further quantitative studies of this phenomenon would be profitable for this or other species.

The epidermis was significantly thicker in nonparental than in parental adults. This, and the significant negative correlation between epidermal thickness and amount of contacting by young fish (Table 2) at first seems contradictory to the findings for other cichlids. Hildemann (1959) reported a thicker epidermis in parental discus fish, and Blüm (1968) stated that epidermal thickening was a characteristic of the parental phase of several cichlid species. In fact, this seeming contradiction may not be so.

In $C$. citrinellum parental fish likely have a thinner epidermis as a result of contacts by young fish. Certainly, by the late parental stage, young can at times be observed to remove bits of surface material by their contacting behavior. If the young are indeed removing material from the parents by their contacting, it should follow that the more contacting a parent receives, the more material it should lose. Thus a highly preferred parent should have a thinner epidermis, and this is consonant with the negative correlation between amount of contacting by the young and epidermal thickness of the parent.

This conclusion, however, is of little help in providing information about the cues from the parents to which the young are responding. It does not seem likely that young fish could respond to the thickness of the parental epidermis. But the amount of mucus on the surface could be an important cue, both at close range (visual, tactile, and (or) chemical), or even at longer range (visual and (or) chemical).

Although we have found a correlation between contacting and mucus cells, we still have the question of cause and effect. It is known that irritation, such as contacting probably produces, results in increased mucus production on the scale surface of teleosts (Van Oosten 1957). But we cannot say whether the increase in mucus results from the increase in contacting, or vice versa. Clearly, there are differences in numbers of mucus cells among different parental fish, and the young might be responding to these. However, without direct tests of the response of young to various cues from the parents, we cannot yet conclude which are the critical cues in the discrimination involved in their contacting preferences.

\section{Acknowledgments}

This research has been supported in part by grant GB 32416 to G. W. Barlow from the National Science Foundation, U.S.A. I thank Dr. G. W. Barlow for advice, material support, encouragement, and extensive helpful criticism of an earlier version of this manuscript, and $A$. Ewing and J. F. Leatherland for use of photographic facilities. This work was begun in the Zoology Department, University of California, Berkeley, California, U.S.A., and was completed in Edinburgh, Scotland.

Baerends, G. P., and J. M. Baerends-van Roon. 1950. An introduction to the study of the ethology of cichlid fishes. Behaviour (Suppl.), 1: 1-242.

BARLOW, G. W. 1973. Competition between color morphs of the polychromatic Midas cichlid Cichlasoma citrinellum. Science (Wash.), 179: 806-807.

BLÜM, V. 1968. Immunological determination of injected mammalian prolactin in cichlid fishes. Gen. Comp. Endocrinol. 11: 595-602.

HEINRICH, W. 1967. Untersuchungen zum Sexualverhalten in der Gattung Tilapia (Cichlidae: Teleostei) und bei Artbastarden. Z. Tierpsychol. 24: 684-754. 
HildemanN, W. H. 1959. A cichlid fish Symphysodon discus, with unique nurture habits. Am. Nat. 93: 27-34. Humason, G. L. 1962. Animal tissue techniques. W. H. Freeman, San Francisco.

KUENZER, P. 1968. Die Auslösung der Nachfolgreaktion bei erfahrungslosen Jungfischen von Nannacara anomala (Cichlidae). Z. Tierpsychol. 25: 257-314.

KüHME, W. 1962. Das Schwarmverhalten eltengeführter Jungcichliden (Pisces). Z. Tierpsychol. 19: 513-538.

NoAKES, D. L. G. 1971. Ontogeny of behavior in a polymorphic cichlid fish, Cichlasoma labiatum (Günther). Doctoral dissertation, University of California, Berkeley, California.

NoAKes, D. L. G., and G. W. Barlow. 1968. Parental behavior of Cichlasoma labiatum-response of young toward the parents. Am. Zool. 8: 691.

1973a. Cross-fostering and parent-offspring responses in Cichlasoma citrinellum (Pisces, Cichlidae). Z. Tierpsychol. In press.
$1973 \mathrm{~b}$. Ontogeny of parent-contacting behavior in young Cichlasoma citrinellum (Pisces, Cichlidae). Behaviour. In press.

Noble, G. K., and B. Curtis. 1939. The social behavior of the jewel fish, Hemichromis bimaculatus Gill. Am. Mus. Nat. Hist. Bull. 76: 1-46.

Peters, H. M. 1963. Untersuchungen zum Problem des angeborenen Verhaltens. Naturwissenschaften, 22: 677-686.

SIEGEL, S. 1956. Nonparametric statistics for the behavioral sciences. McGraw-Hill, New York.

VAN OOSTEN, J. 1957. The skin and scales. In The physiology of fishes. Edited by M. E. Brown. Academic Press, New York. pp. 207-244.

WARD, J. A., and G. W. BARLOW. 1967. The maturation and regulation of glancing off the parents by young orange chromides (Etroplus maculatus: Pisces, Cichlidae). Behaviour, 29: 1-56.

\section{Plate 1}

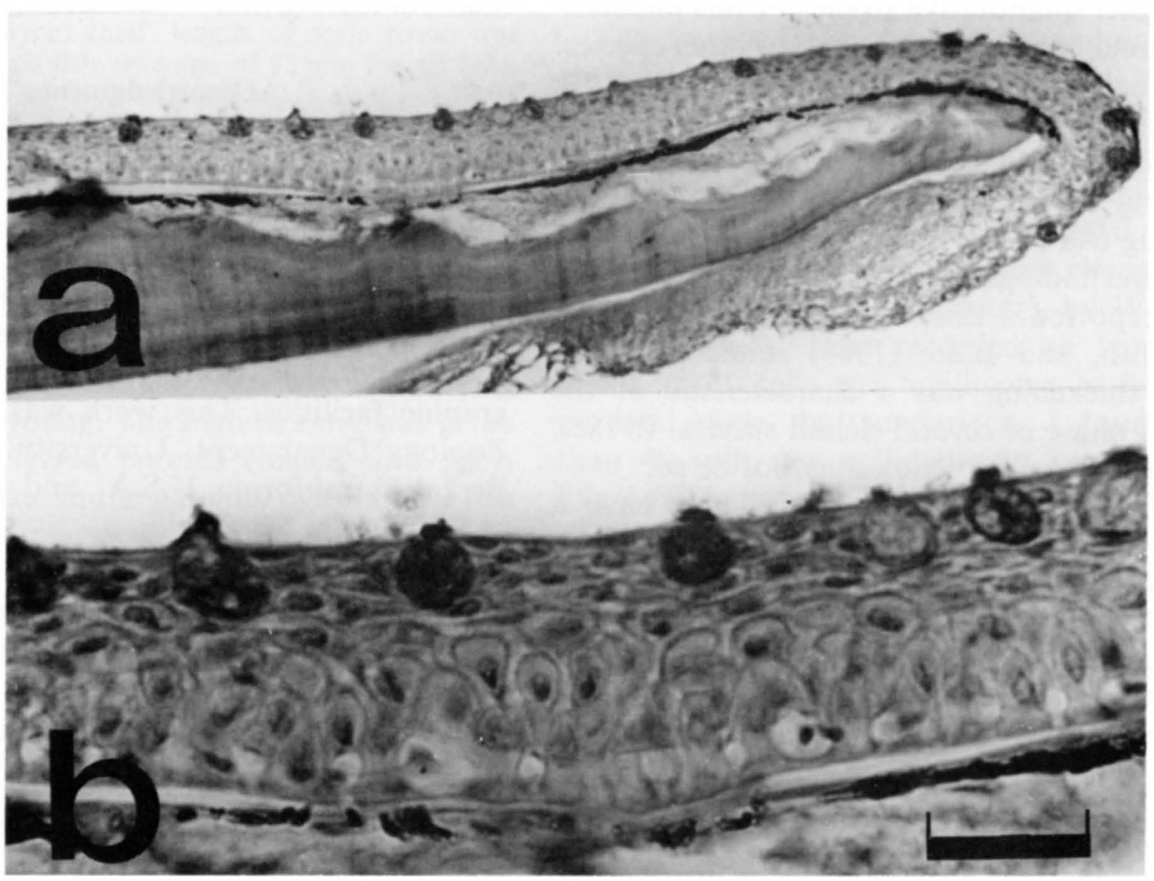

Fig. 1. Section of scale of parental adult $C$. citrinellum. (a) Tip of scale to show location of mucus cells (upper surface). (b) Enlarged area to show individual mucus cells. Bar represents $10 \mu \mathrm{m}$. 